\title{
Implantation of Autologous Bone-Marrow-Derived Cells Reconstructs Functional Urethral Sphincters in Rabbits
}

\author{
Tetsuya Imamura, Ph.D., Osamu Ishizuka, M.D., Ph.D., Yoshiaki Kinebuchi, Ph.D., M.D., \\ Yoshiki Kurizaki, M.D., Tsuyoshi Nakayama, Ph.D., M.D., Masakuni Ishikawa, M.D., \\ and Osamu Nishizawa, M.D., Ph.D.
}

The purpose of this study was to determine if implantation of autologous bone-marrow-derived cells has the potential to treat stress urinary incontinence caused by intrinsic sphincter deficiency. Bone marrow cells harvested from femurs of New Zealand White rabbits were cultured for 10 days. Seven days before implantation, the urethral sphincters located at the internal urethral orifice were cryo-injured by spraying liquid nitrogen for $15 \mathrm{~s}$. The cultured autologous bone-marrow-derived cells were implanted 7 days after cryo-injury. For controls, cell-free solutions were injected. At 7 and 14 days after implantation, leak point pressures were determined and the urethral sphincters were examined by immunohistochemistry. At 7 and 14 days, the cell-implanted regions contained numerous striated and smooth muscle-like cells expressing myoglobin and smooth muscle actin, respectively. The proportions of myoglobin- and smooth muscle actin-expressing areas in both the 7- and 14-day cell-implanted regions were significantly higher than in controls. By 14 days, these differentiated cells formed contacts with similar cells, creating layered muscle structures. At that time, the leak point pressure of the cellimplanted rabbits was significantly higher than that of the controls. In conclusion, autologous bone-marrowderived cells can reconstruct functional urethral sphincters.

\section{Introduction}

S TRESS URINARY INCONTINENCE (SUI) is an involuntary leakage of urine that occurs during physical activity, such as coughing, sneezing, or lifting heavy objects, and is the most common type of urinary incontinence. ${ }^{1,2}$ The worldwide number of patients having SUI is estimated to be over 200 million. ${ }^{1,2}$ SUI can be grouped into two major categories, urethral hypermobility and intrinsic sphincter deficiency. ${ }^{3}$ The urethral hypermobility-related SUI, which results from loss of bladder neck support, ${ }^{4,5}$ can be improved by surgical therapies to lift the bladder and urethra. ${ }^{6-9}$ The intrinsic sphincter deficiency, characterized by a severely decreased urethral closure pressure due to malfunction of the closure mechanism, results in intractable SUI. ${ }^{10}$ Approximately $20 \%$ of SUI patients are affected by this form, which can occur as a result of radical prostatectomy, ${ }^{11,12}$ bladder neck surgery, ${ }^{13}$ or neurogenic and idiopathic diseases in urinary sphincters. ${ }^{14-17}$ In these cases, improvement of urinary continence requires increased urethral closure pressure. Injection of a bulking agent, such as collagen, into the periurethral tissue, ${ }^{18-21}$ and surgical implantation of a device, such as artificial urinary sphincter ${ }^{22,23}$ have been widely accepted as treatments for the intrinsic sphincter deficiency- related SUI. For the majority of patients, the benefits of these treatments are not enough because the continence rate sharply decreases with time, ${ }^{24,25}$ or the injection or implantation of these materials can cause severe side effects, such as inflammation, foreign giant cell responses, abscesses, erosions, and voiding dysfunction. ${ }^{26-29}$ Therefore, the intrinsic sphincter deficiency-related SUI has few effective treatments.

In the urinary continence system, urethral closure pressure for prohibiting the release of urine is produced by the urethral sphincter, composed of striated and smooth muscle cells. Thus, replacement, enhancement, or recovery of the striated and smooth muscle in the urethral sphincter has great potential to be developed as a treatment for the intrinsic sphincter deficiency-related SUI.,30 Our strategy to accomplish the regeneration of functional urethral sphincters is the utilization of autologous bone-marrow-derived cells. These cells are capable of differentiating both in vitro and in vivo along multiple pathways that include striated and smooth muscle $^{31}$ as well as bone, cartilage, adipose, neural cells, tendon, and connective tissue. ${ }^{32-34}$ Further, in the translation to clinical therapy, autologous cells are superior to allogenic cells because the autologous cells are not burdened with immunological rejection or ethics problems. In this study, we injured rabbit urethral sphincters, resulting in the loss of the majority

Department of Urology, Shinshu University School of Medicine, Matsumoto, Japan. 
of striated and smooth muscle cells and reduced urinary continence. We then determined if autologous bone-marrowderived cells implanted into the injured urethral sphincters could differentiate into striated and smooth muscle and reconstruct functional urethral sphincters.

\section{Materials and Methods}

\section{Animals}

Twenty-four female New Zealand White (NZW) rabbits (Japan SLC Inc., Shizuoka, Japan) at postnatal week 10 were used for the experiments. Animals were treated in accordance with National Institutes of Health Animal Care Guidelines, and the guidelines approved by the Animal Ethics Committee of Shinshu University School of Medicine.

\section{Harvest and culture of autologous bone marrow cells}

To harvest bone marrow cells without euthanasia, we modified the method reported by Kushida et al. ${ }^{35}$ Sixteen NZW rabbits were anesthetized by inhalation of sevoflurane (Sevofrane $^{\circledR}$; Abbot Japan Co., Ltd., Tokyo, Japan). In each animal, two pediatric bone marrow needles were inserted $2 \mathrm{~cm}$ apart into a femur. One needle was connected to a syringe filled with $20 \mathrm{~mL}$ saline. The bone marrow cells were flushed out with the saline and collected through the other needle, which was connected by extension tubing that terminated in a $50-\mathrm{mL}$ collection tube. The suspended cells were mixed with $20 \mathrm{~mL}$ of the culture medium composed of $4.5 \mathrm{~g} /$ L glucose-Dulbecco's modified Eagle's medium (Invitrogen Life Technologies, Carlsbad, CA) supplemented with 15\% regular fetal bovine serum (Biowest, Paris, France) and 0.1\% penicillin-streptomycin (Invitrogen Life Technologies). The diluted cell suspension was then filtered through $40 \mu \mathrm{m}$ nylon mesh filters (BD Biosciences, San Jose, CA). After centrifugation at $1000 \mathrm{rpm}$ for $4 \mathrm{~min}$, the cells were resuspended with the culture medium.

The harvested bone marrow cells were cultured on type I collagen-coated $75-\mathrm{cm}^{2}$ culture flasks (Asahi Glass Co., Ltd., Tokyo, Japan) with the culture medium for 10 days at $37^{\circ} \mathrm{C}$ with $5 \% \mathrm{CO}_{2}$. During the culture, the medium was completely replaced every other day, and nonattached cells were discarded. Eight days after seeding, the cells were transfected with a plasmid DNA encoding the green fluorescence protein (GFP) gene according to our previous study. ${ }^{36}$ Briefly, we transfected the plasmid DNA encoding GFP gene $(10 \mu \mathrm{g}$, pAcGFP I; BD Biosciences) into the cells by using Lipofectamine 2000 Reagent (Invitrogen Life Technologies). At 2 days after transfection, GFP-labeled, adherent, proliferating bone-marrow-derived cells were dissociated with $0.25 \%$ trypsin (Invitrogen Life Technologies) in phosphate-buffered saline (PBS), and suspended at $0.5 \times 10^{7}$ cells $/ \mathrm{mL}$ with the culture medium.

\section{Production of cryo-injured urethral sphincters}

Seven days before implantation, the same NZW rabbits from which the cells had been harvested were anesthetized as above. The urinary bladders were exposed through an abdominal midline incision, and then the anterior walls of the urinary bladders were incised. The urethral sphincters, which were located at the internal urethral orifice at the inferior end of the bladder and the proximal end of the urethra at the junction of urethra with the urinary bladder, were sprayed with the liquid nitrogen for $15 \mathrm{~s}$ (Cryo Pro ${ }^{\circledR}$; Cortex Technology, Hudsund, Denmark). The urinary bladder was then surgically closed and returned to the pelvic cavity.

We determined the degree of damage due to freezing 7 days after cryo-injury. In addition to cryo-injured rabbits $(n=4)$, four others were treated identically except that the urethral sphincters were not sprayed with liquid nitrogen. These served as sham-injured rabbits. At 7 days after the operations, we measured the leak point pressure and removed the lower urinary tracts for histological investigations (described below).

\section{Implantation of autologous bone-marrow-derived cells}

Ten days after harvesting the bone marrow cells and placing them in culture, and 7 days after cryo-injury operations, the rabbits were divided into cell implantation $(n=8)$ and cellfree injection control $(n=8)$ groups. After re-anesthetizing the rabbits, the injured regions located at the internal urethral orifice were exposed. For the cell implantation group, the $0.5 \times 10^{6}$ autologous bone-marrow-derived cells suspended in $100 \mu \mathrm{L}$ culture medium were implanted into the injured regions at the 3-, 6-, 9-, and 12-o'clock positions with 29-gauge syringes. The total number of cells injected was $2.0 \times 10^{6}$. For the cell-free injection control group, $100 \mu \mathrm{L}$ of the cell-free culture medium was similarly injected. The implantation cell number and volume were chosen to avoid further damaging the host tissues or the implanted cells with shear stress. At each operation, the retention of small swellings that included the implanted cells or control media was visually confirmed. At 7 and 14 days after implantation, cystometric investigations $(n=4$, in each group and at each day) were performed (described below). Immediately following these physiological studies, the lower urinary tracts, including the cell-implanted and the control-injected regions, were removed for immunohistochemical investigations (described below).

\section{Immunohistochemistry}

Tissue samples were fixed in $4 \%$ paraformaldehyde and $4 \%$ sucrose in $0.1 \mathrm{M}$ phosphate buffer, $\mathrm{pH} 7.4$, for $12 \mathrm{~h}$ at $4{ }^{\circ} \mathrm{C}$, and then decalcified with $10 \%$ ethylenediaminetetraacetic acid solution (Osteosoft ${ }^{\circledR}$; Merck KGaA, Darmstadt, Germany) for $12 \mathrm{~h}$ at $\mathrm{pH} 7.2$ and $4{ }^{\circ} \mathrm{C}$. The treated samples were embedded in paraffin, and cut in 5 - $\mu \mathrm{m}$-thick serial sections. The sections were deparaffinized, rehydrated, rinsed three times with PBS, and immersed in $10 \mathrm{mM}$ sodium citrate, $\mathrm{pH}$ 6.0. For antigen retrieval, they were then microwaved at $100{ }^{\circ} \mathrm{C}$ for $5 \mathrm{~min}$. The specimens were coated with $1.5 \%$ normal donkey serum (Chemicon International Inc., Temecula, CA) and $1.5 \%$ nonfat milk in PBS for $1 \mathrm{~h}$ at $4{ }^{\circ} \mathrm{C}$.

To detect implanted bone-marrow-derived cells, the sections were incubated for $12 \mathrm{~h}$ at $4^{\circ} \mathrm{C}$ with GFP antibody (1:500, mouse monoclonal; Chemicon International Inc.). The sections were rinsed with PBS at $4^{\circ} \mathrm{C}$, and then incubated with secondary antibody consisting of donkey anti-mouse IgG conjugated with Alexa fluor 488 (1:250; Molecular Probes, Eugene, OR) for $1 \mathrm{~h}$ at $4^{\circ} \mathrm{C}$. Additionally, cultured bone-marrow-derived cells transfected with GFP were similarly stained on day 10 of culture, 2 days after transfection.

Following subsequent rinsing, the sections were then incubated for $12 \mathrm{~h}$ at $4^{\circ} \mathrm{C}$ with antibodies for myoglobin (1:200, rabbit polyclonal; Spring Bioscience Inc., Pleasanton, CA), 
alpha-smooth muscle actin (SMA, 1:100, mouse monoclonal; Progen Biotechnik GmbH, Heidelberg, Germany), or Pax7 (1:1000, rabbit; LifeSpan Bioscience Inc., Seattle, WA) antibody as markers for striated muscle cells, smooth muscle cells, and myoblasts, respectively. The sections were rinsed with PBS at $4^{\circ} \mathrm{C}$, and then incubated with secondary antibody consisting of donkey anti-rabbit or mouse IgG conjugated with Alexa fluor 594 (1:250; Molecular Probes) for $1 \mathrm{~h}$ at $4^{\circ} \mathrm{C}$. Following rinsing, they were counterstained with $4^{\prime}, 6-$ diamidino-2-phenylindole dihydrochloride $(5 \mu \mathrm{g} / \mathrm{mL}$; Molecular Probes), and then coated with Fluorescent Mounting Medium (Dako Cytomation, Carpinteria, CA). The slides were observed and photographed with a Leica DAS Microscopethe (Leica Microsystems $\mathrm{GmbH}$, Wetzlar, Germany). Other sections from each sample were stained with hematoxylin and eosin. Additionally, cultured bone-marrowderived cells transfected with GFP were similarly double stained with GFP and myoglobin or SMA antibodies as above on day 10 of culture, 2 days after GFP transfection.

Using an image analysis program (Image-Pro ${ }^{\circledR}$ Plus; Media Cybernetics Inc., Bethesda, MD), the areas of fluorescence markers of anti-myoglobin and anti-SMA at the $3-, 6-, 9-$, and 12-o'clock positions of the internal urethral orifice in each slide were semiquantitatively evaluated.

\section{Electron microscopy}

Before the cell implantation experiments, we analyzed by transmission electron microscopy sham-injured $(n=4)$ and cryo-injured $(n=4)$ urethral sphincters 7 days after wounding. The tissues were fixed overnight in $2.5 \%$ glutaraldehyde in $45 \mathrm{mM}$ cacodylate buffer, $\mathrm{pH}$ 7.2. The glutaraldehydefixed specimens were washed three times in $180 \mathrm{mM}$ sucrose in $80 \mathrm{mM}$ cacodylate buffer at $4^{\circ} \mathrm{C}$ for $3 \mathrm{~h}$, and then postfixed in $1 \%$ osmium tetroxide in $0.1 \mathrm{M}$ sodium cacodylate buffer for $60 \mathrm{~min}$ at $4^{\circ} \mathrm{C}$. The specimens were dehydrated in a graded series of ethanol and embedded in epoxy resin. Ultrathin sections were stained with uranyl acetate and lead citrate. These samples were observed with a JEOL JEM-1200 transmission electron microscope (JEOL Ltd., Tokyo, Japan) at an accelerating voltage of $80 \mathrm{kV}$.

\section{Measurement of leak point pressure}

At 7 and 14 days after cell-implantation and cell-free control injection, the animals $(n=4$, in each group and at each day) were anesthetized as above. A polyethylene catheter (PE90; Nippon Becton Dickinson, Tokyo, Japan) was inserted into the exposed bladder top, and fixed at that site with a 5-0 silk thread. The urinary bladder was connected via the inserted catheter to a pressure transducer (P23 DC; Statham, Oxnard, CA) and a microinjection pump (Model 200; Muromachi-Kikai, Tokyo, Japan). Saline maintained at room temperature was instilled into the urinary bladder at a rate of $10 \mathrm{~mL} / \mathrm{h}$. The internal bladder pressures were recorded continuously on a pen oscillograph $(10 \mathrm{~mm} / \mathrm{min}$ recording speed, Recti-Horiz-8K; NEC San-ei Instruments, Tokyo, Japan). The internal bladder pressure sufficient to cause leakage from the urethra was recorded as the leak point pressure.

\section{Statistical analysis}

Results were expressed as means \pm standard deviation. We used the Excel $^{\circledR}$ statistical program (Esumi Co., Ltd.,
Tokyo, Japan) to determine statistical differences by unpaired $t$-tests. Differences with $p<0.05$ were considered significant.

\section{Results}

\section{Autologous bone-marrow-derived cells}

To conduct autologous implantation, we harvested bone marrow cells from a femur of each anesthetized animal by the flush out method (Fig. 1A). Immediately after plating in collagen-coated culture flasks, the newly harvested bone marrow cells consisted of heterogeneous, spindle-shaped, round, and polygonal cells along with red blood cells. Eight days after seeding, the cells were attached to the flasks and had achieved $\sim 80 \%$ confluence. At that time, they were transfected with the GFP gene for identification in the recipient tissues. Two days after transfection, the adhered proliferating cells were relatively homogenous in spindleshaped appearance, and 90\% stained with GFP antibody (Fig. 1B). The cultured cells were not positive for striated and smooth muscle cell differentiation marker antibodies (Fig. 1C and $\mathrm{D}$, respectively).

\section{Cryo-injured urethral sphincter models}

We cryo-injured the urethral sphincters, which were located at the internal urethral orifice (Fig. 1E), with liquid nitrogen spray. The frozen regions were thawed by room and body temperature within $\sim 20 \mathrm{~s}$. Immediately afterward, the wounded internal urethral orifice was flaccid and gaped open (Fig. 1F). Before the cell-implantation experiments, we examined 7-day-old sham-injured and cryo-injured urethral sphincters. The sham-injured internal urethral orifices were tightly closed by the musculature of the urethral sphincters (Fig. 2A). The muscle tissues within the intact urethral sphincters (Fig. 2B) were composed of striated muscle cells having a distinct striped appearance formed by regularly placed myofibrils and smooth muscle cells having irregularly placed myofibrils (Fig. 2C). In contrast, the 7-day-old cryoinjured internal urethral orifices appeared to be relaxed, creating a larger orifice (Fig. 2D). The injured urethral sphincters showed reactive changes, including loss of muscle mass and the relative disorganization of the remaining muscle tissues (Fig. 2E). The injured urethral sphincters lost the majority of the typical striated and smooth muscle cells (Fig. 2F). Immunohistochemistry showed that the shaminjured urethral sphincters had distinct muscle tissues composed of numerous myoglobin- and SMA-positive cells (Fig. $2 \mathrm{G}$ and $\mathrm{H}$, respectively). However, the cryo-injured urethral sphincters had little muscle tissue that was composed of myoglobin- and SMA-positive cells (Fig. 2I and J, respectively). The leak point pressure of the animals having the injured urethral sphincter, $7.33 \pm 0.27 \mathrm{~cm} \mathrm{H}_{2} \mathrm{O}$, was significantly lower $(p<0.01)$ than in the sham-injured animals, $12.58 \pm 1.26 \mathrm{~cm} \mathrm{H}_{2} \mathrm{O}$.

\section{Reconstruction of layered muscle structures in urethral sphincters}

At 7 and 14 days after cell-implantation and cell-free control injection, the urethral sphincters were analyzed by histology and cytology. At 7 days after cell-free control injection, there were a few striated muscle cells with regularly 

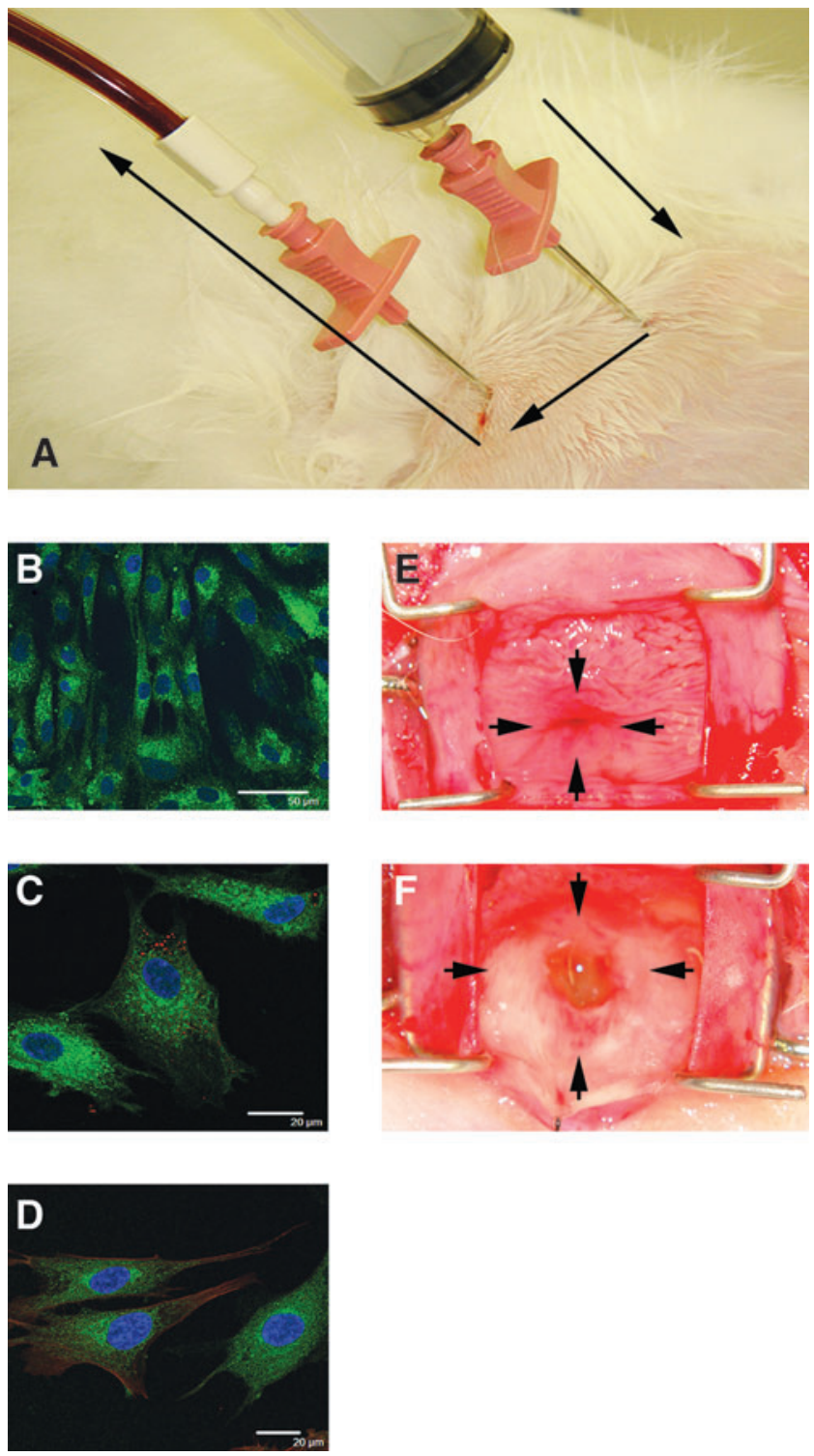

FIG. 1. Cultured autologous bone-marrow-derived cells and cryo-injured urethral sphincters. (A) The bone marrow cells were corrected by flushed out methods. Arrows: saline flow. (B) At 10 days after culture, the adhered and proliferating bone-marrow-derived cells were spindle-shaped and expressed green fluorescence protein (GFP) (green). Blue: nuclei. Bar: $50 \mu \mathrm{m}$. (C) Just before implantation, the cultured cells (green) were not positive for myoglobin antibody. Blue: nuclei. Bar: $20 \mu \mathrm{m}$. (D) Also, the cells were not positive for smooth muscle actin (SMA) antibody. Blue: nuclei. Bar: $20 \mu \mathrm{m}$. (E) Just before cryo-injury, the urethral sphincters were tightly closed (arrows). (F) Approximately $20 \mathrm{~s}$ after spraying, the wounded internal urethral orifice (arrows) was flaccid and gaped open.

placed myofibrils and smooth muscle cells with irregularly placed myofibrils (Fig. 3A, B). In contrast, the 7-day cellimplanted regions had developing muscle layers composed of striated and smooth muscle cells (Fig. 3C, D). At 14 days after control injection, the regions were similar to the 7-day control regions (Fig. 3E, F). The 14-day cell-implanted regions had distinctly regenerated muscle layers composed of numerous striated and smooth muscle cells, which were similar to the intact urethral sphincters (Fig. 3G, H).

We analyzed the cell-free control-injected and cellimplanted urethral sphincters by immunohistochemistry. The 7-day cell-free control-injected regions had a few myoglobin-positive cells (Fig. 4A). In contrast, the 7-day cellimplanted regions had abundant myoglobin-positive cells compared to control regions (Fig. 4B). The proportion of myoglobin-expressing area in the 7-day cell-implanted regions was significantly higher than that in the 7-day control ones (Fig. 4C, $p<0.01$ ). At 14 days after control cell-free injection, the presence of cells expressing myoglobin was similar to the 7-day control regions (Fig. 4D). In contrast, at 14 days after cell implantation, there were numerous myoglobinpositive cells (Fig. 4E). These cells formed distinct striated muscle layers that were similar to those in intact urethral sphincters. The proportion of myoglobin-expressing area in the 14-day cell-implanted regions was also significantly higher than that in the 14-day control ones (Fig. 4F, $p<0.01$ ).

At 7 days, both cell-free control-injected (Fig. 5A) and cell-implanted (Fig. 5B) regions had several clusters composed of the SMA-positive cells. However, the proportion of SMA-expressing area in the cell-implanted regions was significantly higher than in the controls (Fig. 5C, $p<0.01$ ). The 14-day control regions also had several clusters formed by the SMA-positive cells; however, these clusters were similar to the 7-day controls (Fig. 5D). Compared to the control regions, the 14-day cell-implanted regions had larger clusters of SMA-positive cells. The clusters were organized into smooth muscle layers similar to the intact urethral sphincters (Fig. 5E). In addition, the proportion of SMA-expressing area in the 14-day cell-implanted regions was also significantly higher than that in the 14-day controls (Fig. 5F, $p<0.01$ ).

\section{Implanted autologous bone-marrow-derived cells}

At 7 and 14 days after implantation, we determined if the cells organized into the reconstructed layered muscle structures were derived from the implanted autologous bonemarrow-derived cells. The tissues were double stained with GFP antibody in combination with striated muscle cell-, smooth muscle cell-, or myoblast differentiation-marker antibodies. At 7 days, some of the implanted cells identified by the presence of GFP antibody (Fig. 6A) were simultaneously positive for myoglobin antibody (Fig. 6B). These doublepositive cells showed that the implanted autologous cells differentiated into striated muscle-like cells. These differentiated cells were widely distributed within the reconstructed muscle layers (Fig. 6C). Also, some GFP-positive implanted cells (Fig. 6D) were simultaneously positive for SMA antibody (Fig. 6E). These double-positive cells showed that the implanted cells differentiated into smooth muscle-like cells. These differentiated cells were also widely distributed within the reconstructed muscle layers (Fig. 6F). At 7 days after implantation, a few GFP-positive cells (Fig. 6G) were simultaneously positive for Pax7 antibody (Fig. 6H). The number of both GFP and Pax7 double-positive cells were a very few (Fig. 6I). The majority of cells double-positive for GFP and for myoglobin, SMA, or Pax7 were mononuclear.

At 14 days after implantation, the GFP-positive cells (Fig. 7A) that were positive for myoglobin (Fig. 7B) appeared to form contacts among themselves, creating striated muscle 

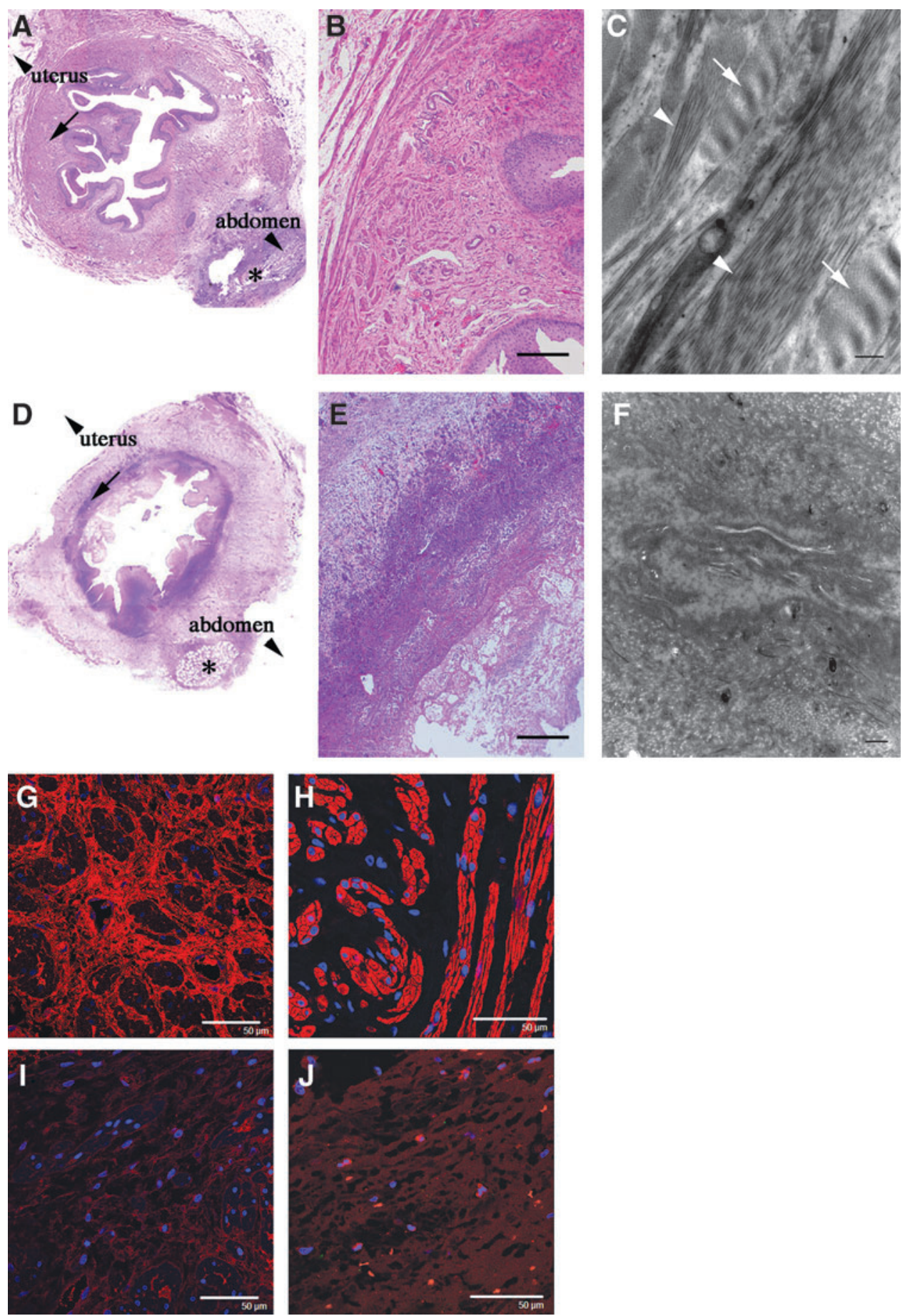

FIG. 2. Histology and cytology of sham-injured and cryo-injured urethral sphincters just before cell implantation. (A) The intact, uninjured urethral orifices from sham-operated animals were tightly closed with surrounding muscle tissues. Arrow: urethral muscle tissue. Left arrowhead: uterus. Right arrowhead: abdomen. Asterisk: suture scar. (B) Enlarged area in (A, arrow) showed that the intact urethral sphincters were composed of distinct muscle tissues. Bar: $100 \mu \mathrm{m}$. (C) The muscle tissues in the intact urethral sphincters were composed of striated muscle cells, which had a distinct striped appearance (arrows), and smooth muscle cells, which had irregularly placed myofibrils (arrowheads). Bar: $1 \mu \mathrm{m}$. (D) At 7 days after wounding, the urethral orifices were flaccid and gaped open due to loss of the surrounding muscle tissues. Arrow: urethral muscle tissue. Left arrowhead: uterus. Right arrowhead: abdomen. Asterisk: suture scar. (E) Enlarged area in (D, arrow) showed that the injured urethral sphincters had reactive changes and loss of muscle tissues. Bar: $100 \mu \mathrm{m}$. (F) Injured urethral sphincters lost the majority of the typical striated and smooth muscle cells. Bar: $1 \mu \mathrm{m}$. (G and $\mathbf{H})$ The intact urethral sphincters had distinct numerous myoglobin-positive (G) and SMA-positive (H) cells (red) that were organized into muscle layers. Blue: nuclei. Bar: $50 \mu \mathrm{m}$. (I and J) The cryo-injured urethral sphincters had few myoglobin-positive (I) and SMA-positive (J) cells. Blue: nuclei. Bar: $50 \mu \mathrm{m}$. 

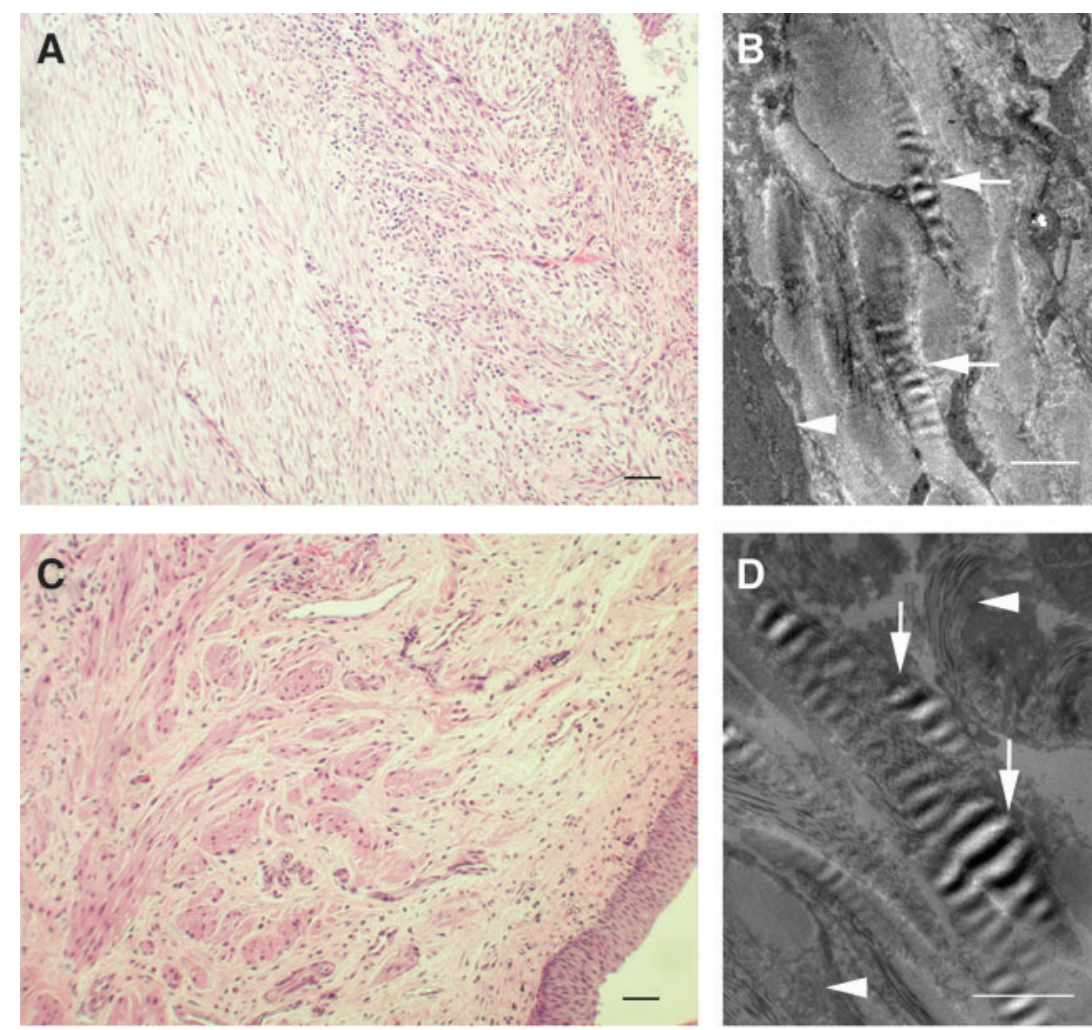

FIG. 3. Histology and cytology of regenerated muscle tissues within the urethral sphincter. (A and B) The 7-day control-injected regions had a few striated and smooth muscle cells. (C and D) The 7-day cell-implanted regions had developing muscle layers composed of striated and smooth muscle cells. (E and F) At 14 days after control injection, the appearances did not change significantly from the sphincters at 7 days. ( $\mathbf{G}$ and $\mathbf{H}$ ) The 14-day cell-implanted regions had distinct muscle layers composed of numerous striated and smooth muscle cells, and similar to the intact ones. Arrows: striated muscle cells. Arrowheads: smooth muscle cells. Black bar: $100 \mu \mathrm{m}$. White bar: $1 \mu \mathrm{m}$. Color images available online at www.liebertonline.com/tea.
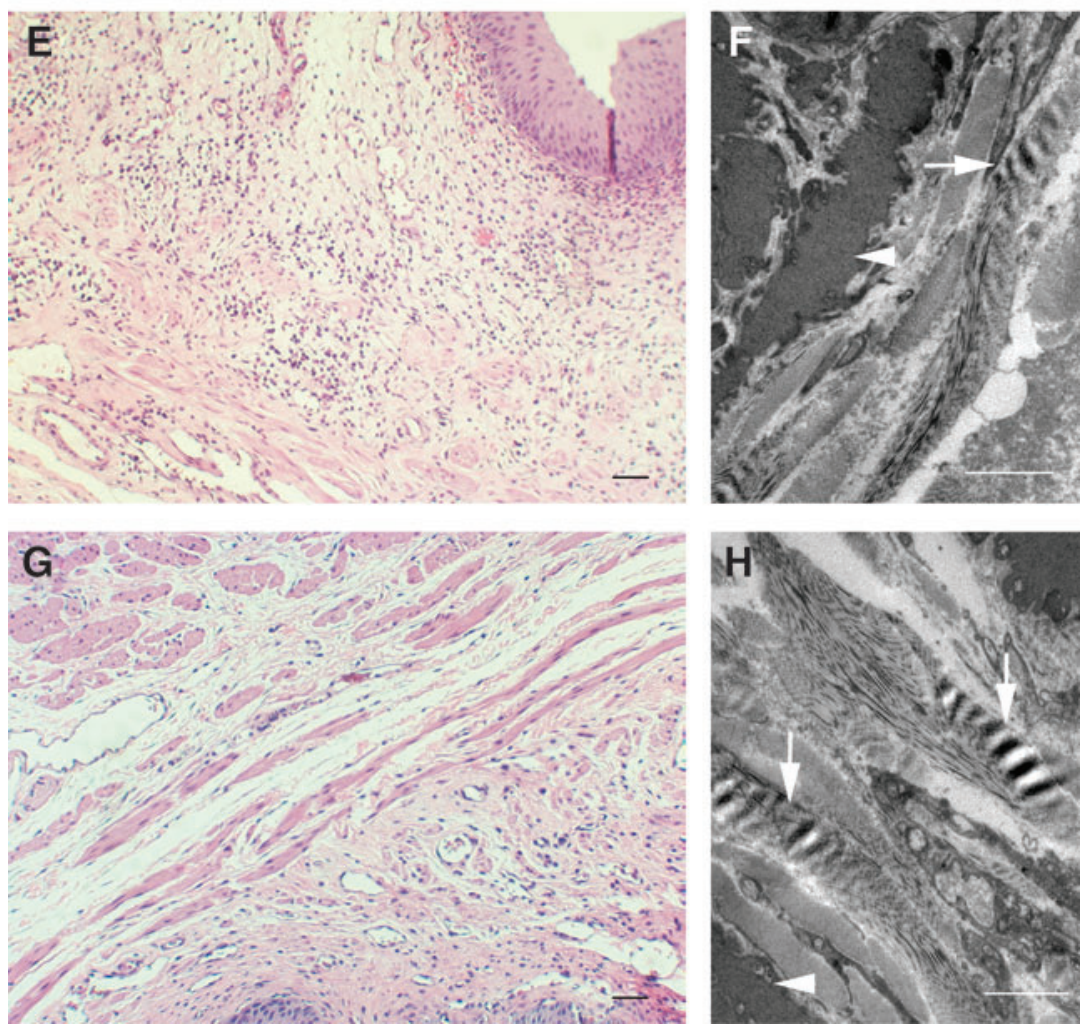

layer-like structures (Fig. 7C). Similarly, the GFP-positive (Fig. 7D) cells that were positive for SMA (Fig. 7E) appeared to form contacts among themselves, creating smooth muscle layer-like structures (Fig. 7C). In addition, the striated- and smooth-muscle differentiated cells contacted non-GFP expressing muscle tissues derived from the uninjured sur- rounding tissues. These cells were then integrated into the recovered muscle layers. Further, differentiated smooth muscle-like cells were also present in blood vessel-like structures (Fig. 7G-I). At the same time, a few GFP-labeled cells (Fig. 7J) were simultaneously positive for Pax7 (Fig. 7K, L), indicating the presence of myoblast-like cells. 

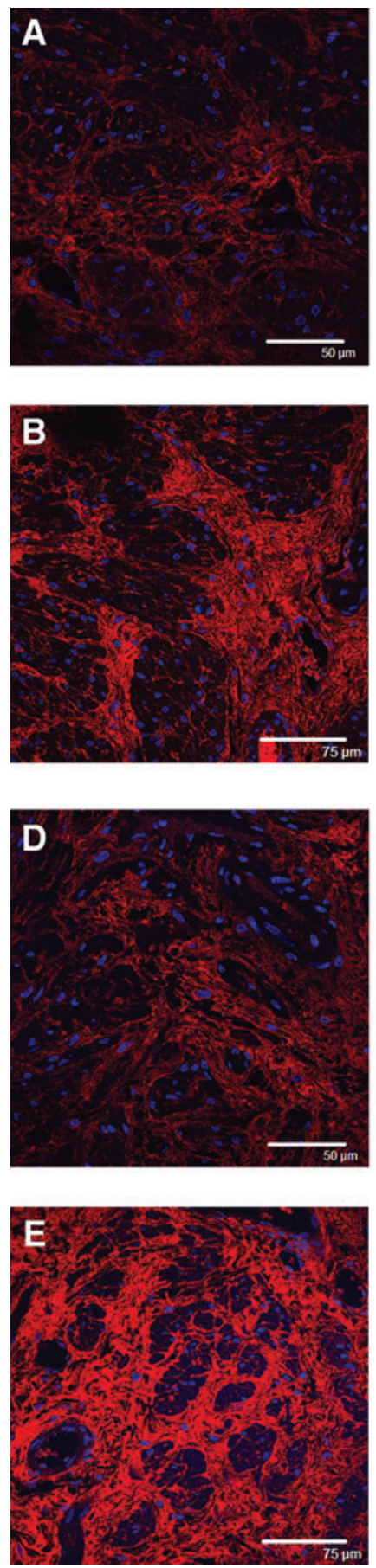
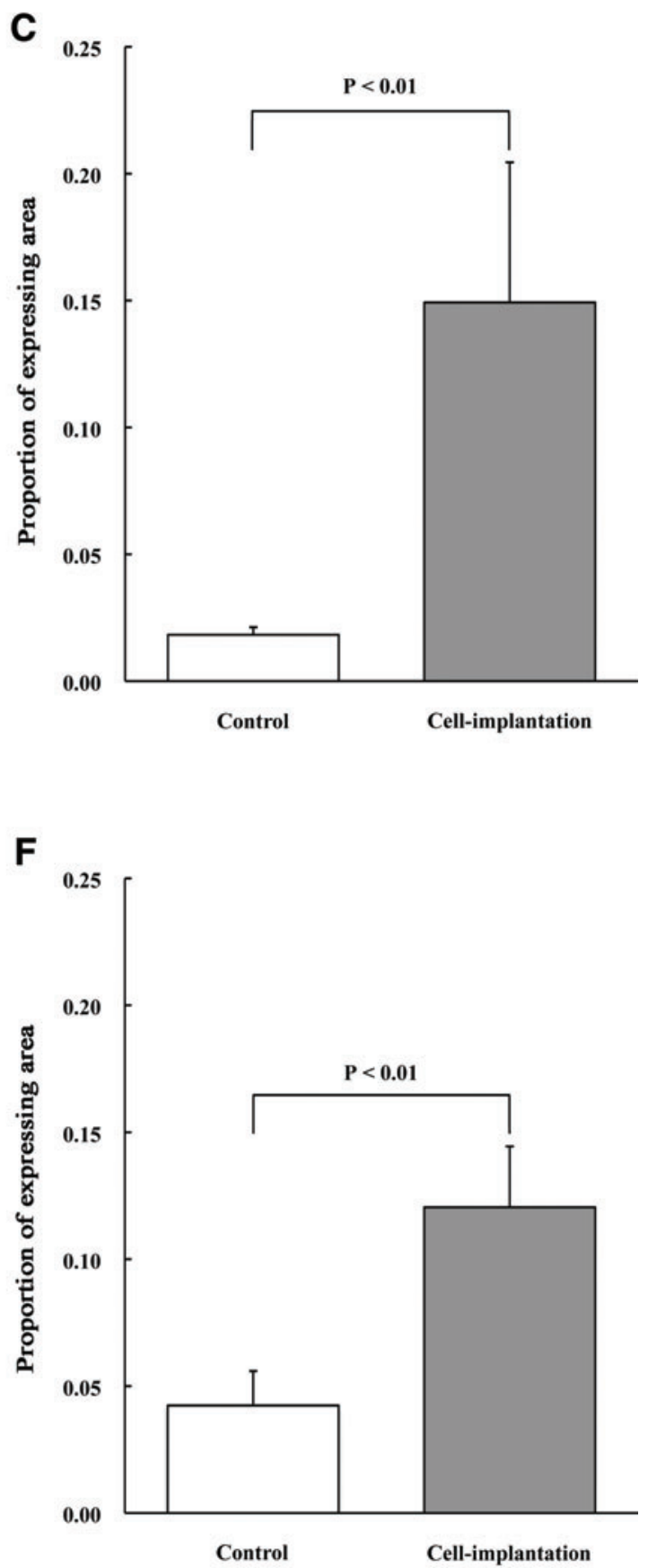

FIG. 4. Reconstruction of muscle layers composed of striated muscle-like cells. (A) Seven days after cell-free control injection, the sphincters had a few myoglobinpositive cells (red). Blue: nuclei. Bar: $50 \mu \mathrm{m}$. (B) The 7-day cell-implanted regions had abundant myoglobin-positive cells (red) compared to controls. Blue: nuclei. Bar: $75 \mu \mathrm{m}$. (C) At 7 days, the proportion of myoglobin-expressing area in the cell-implanted urethral sphincters (right bar) was significantly higher than that in controls (left bar, $p<0.01$ ). (D) At 14 days after cell-free control injection, the regions contained myoglobin-positive cells; however, the presence was similar to the 7-day control regions. Red: myoglobin-positive cells. Blue: nuclei. Bar: $50 \mu \mathrm{m}$. (E) At 14 days after cell-implantation, the sphincters had distinct layered muscle structures organized with the numerous myoglobin-positive cells (red), which were similar to the intact urethral sphincters. Blue: nuclei. Bar: $75 \mu \mathrm{m}$. (F) At 14 days, the proportion of myoglobin-expressing area in the cell-implanted urethral sphincters (right bar) was significantly higher than that in controls (left bar, $p<0.01$ ). Color images available online at www.liebertonline.com/tea.

\section{Recovery of leak point pressure}

At 7 days after cell implantation, the leak point pressure, $13.15 \pm 2.82 \mathrm{~cm} \mathrm{H}_{2} \mathrm{O}$, tended to be higher than the cell-free control group, $8.13 \pm 2.43 \mathrm{~cm} \mathrm{H}_{2} \mathrm{O}$, but the difference was not statistically significant (Fig. 8A). At 14 days, the leak point pressure of the cell-implantation group, $17.82 \pm 1.31 \mathrm{~cm} \mathrm{H}_{2} \mathrm{O}$, was significantly higher than that of the control group, $11.78 \pm 3.23 \mathrm{~cm} \mathrm{H}_{2} \mathrm{O}(p<0.05$, Fig. $8 \mathrm{~B})$.

\section{Discussion}

In many clinical cases, the intrinsic sphincter deficiency induces the intractable SUI. Improvements of urethral clo- sure pressures are widely accepted as one of the effective treatments for this form of SUI. Recently, transurethral cell transplantation of adult stem cells, such as myoblasts ${ }^{37-39}$ or adipose-derived mesenchymal cells, ${ }^{40}$ into urethras produced bulking effects that increased urethral closure pressure. While the novel therapy of using these cells has a great potential to be effective, there is little evidence so far that indicates the occurrence of muscle tissue reconstruction that would be associated with recovery of the functional urethral sphincters.

Our aim was to utilize autologous bone-marrow-derived cells, which display developmental plasticity, ${ }^{32-34}$ to reconstruct functional urethral sphincters that will inhibit urine 
FIG. 5. Reconstruction of muscular structures composed of smooth muscle-like cells. (A) The 7-day cell-free control-injected regions had several clusters of SMApositive cells (red). Blue: nuclei. Bar: $50 \mu \mathrm{m}$. (B) Similarly, the 7-day cell-implanted regions also had clusters of SMA-positive cells (red). Blue: nuclei. Bar: $50 \mu \mathrm{m}$. (C) At 7 days, the proportion of SMAexpressing area in the cellimplanted urethral sphincters (right bar) was significantly higher than that in control ones (left bar, $p<0.01$ ). (D) The 14-days control regions also had several clusters; however, they were similar to the 7-day control regions. Red: SMApositive cells. Blue: nuclei. Bar: $50 \mu \mathrm{m}$. (E) The 14-day cellimplanted regions had larger clusters of SMA-positive cells compared to the 14-day control regions. Blue: nuclei. Bar: $50 \mu \mathrm{m}$. (F) At 14 days, the proportion of SMAexpressing area in the cellimplanted urethral sphincters (right bar) was significantly higher than that in controls (left bar, $p<0.01)$. Color images available online at www.liebertonline .com/tea.
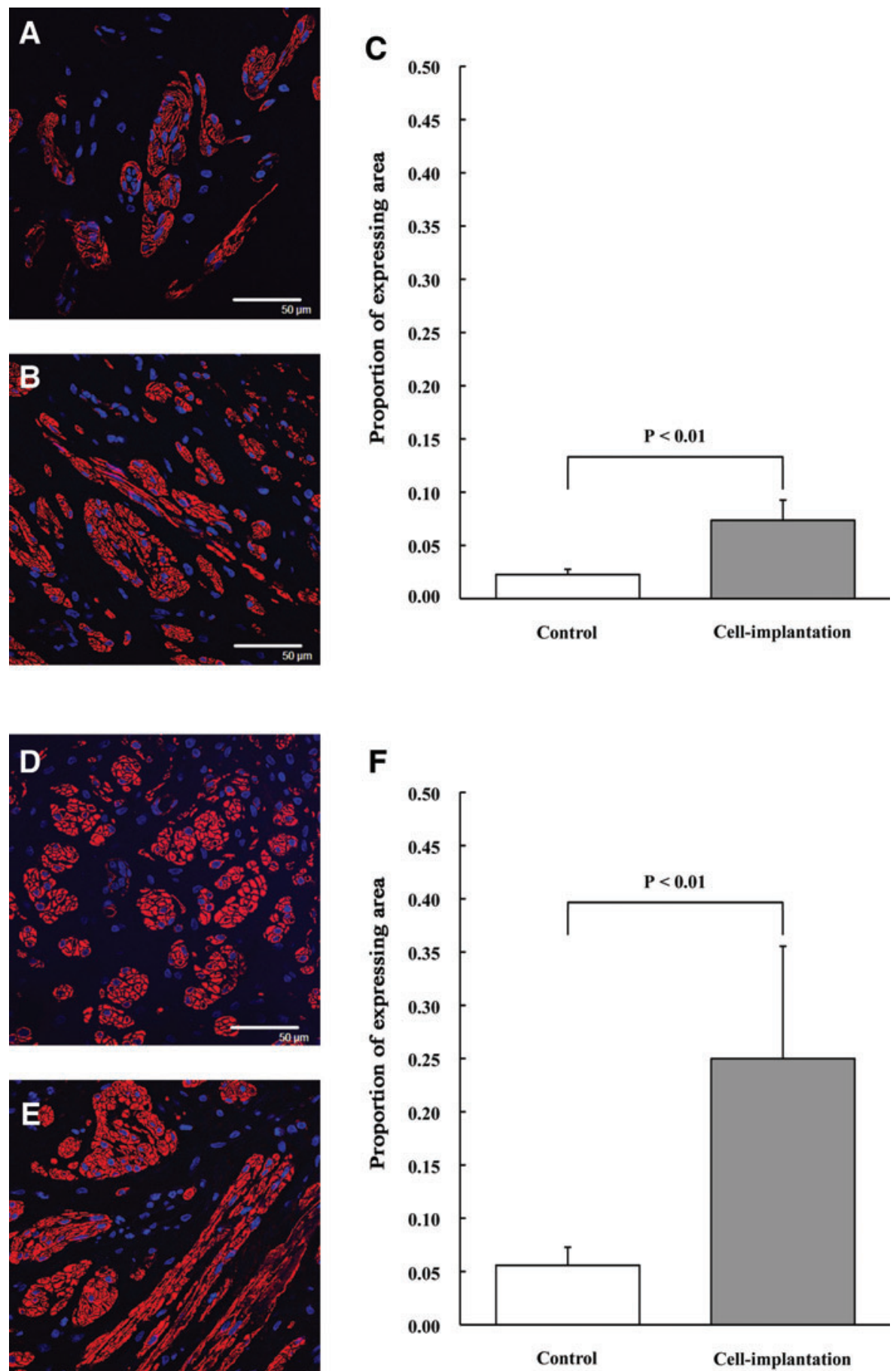

leakage. Bone-marrow-derived cells are especially suited for this purpose because they can differentiate into striated or smooth muscle cells, both in vitro and in vivo. ${ }^{31}$ Previously, we showed that bone-marrow-derived cells of wild-type mice, when implanted into freeze-injured urinary bladders of nude mice where most of the smooth muscle was lost, differentiate into smooth muscle cells. ${ }^{36}$ Further, the bonemarrow-derived cells, when situated in areas of damage, produce cytokines and growth factors based on available signals in the surrounding tissues. ${ }^{41,42}$ The majority of the patients having intrinsic sphincter deficiency-related SUI are elderly and have other diseases. Aging and/or disease processes may affect the potential of bone marrow cells for differentiation, and this needs to be investigated the appropriate animal models. However, in the study reported here, we used young and healthy rabbits to investigate the potential for urethral reconstruction as first step investigation. We harvested bone marrow cells and then cryo-injured the urethral sphincters in the same animal, enabling later implantation of autologous bone-marrow-derived cells. The cryo-injury resulted in the loss of the majority striated and smooth muscle cells that were located at the internal urethral 

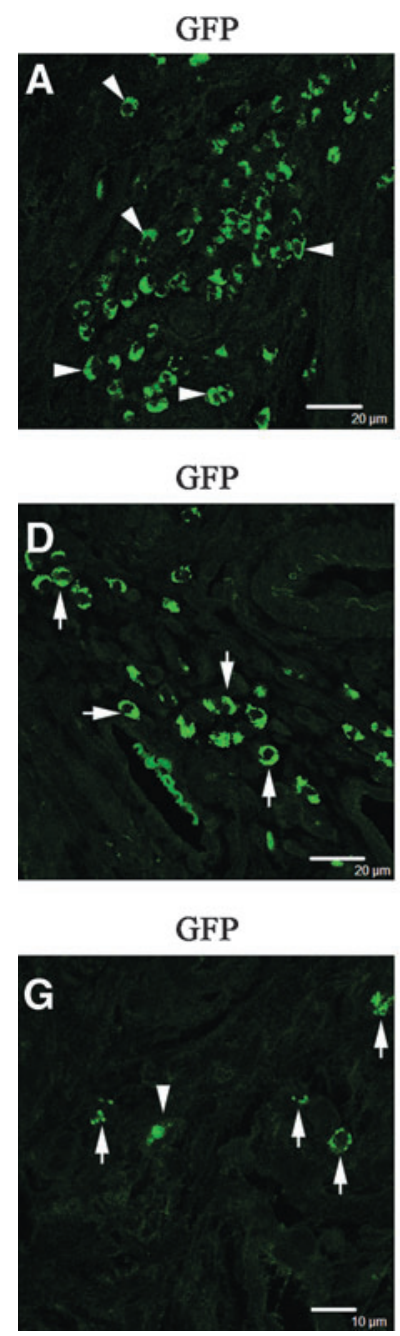

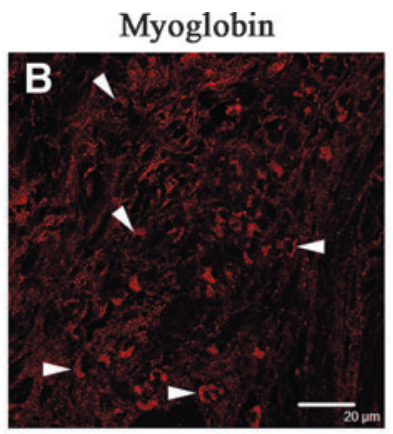

SMA

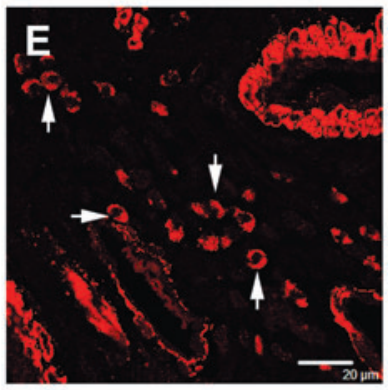

$\operatorname{Pax} 7$

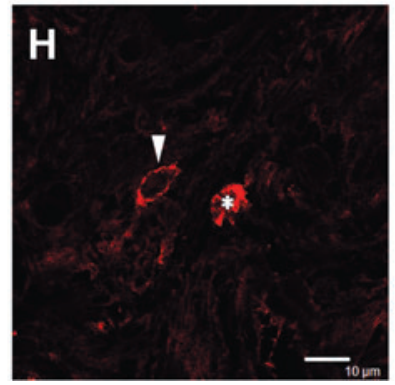

Merged image

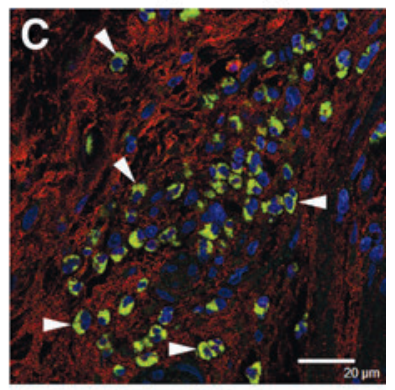

Merged image

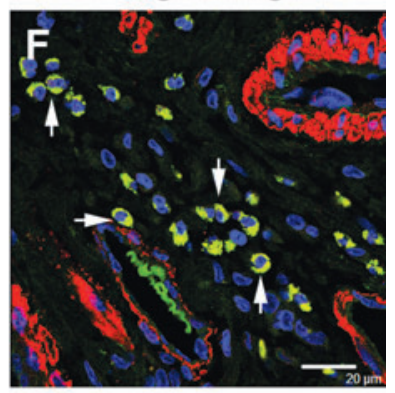

Merged image

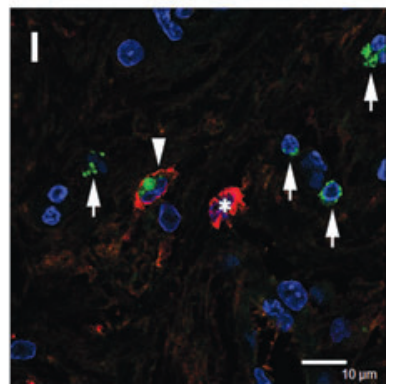

FIG. 6. Differentiation at 7 days after implantation of autologous bone-marrow-derived cells into striated and smooth muscle-like cells. (A-C) Some of the GFPpositive cells (A, green, arrowheads) were simultaneously positive for myoglobin antibody (B, red, arrowheads). The cells differentiated into striated musclelike cells (C, yellow, arrowheads) were widely distributed within the reconstructed muscle layers. Blue: nuclei. Bar: $20 \mu \mathrm{m}$. (D-F) Similarly, some of the GFP-positive cells (D, green, arrows) were simultaneously positive for SMA antibody (E, red, arrows). The cells differentiated into smooth muscle-like cells ( $\mathbf{F}$, yellow, arrows) were also widely distributed within the reconstructed muscle layers. Blue: nuclei. Bar: $20 \mu \mathrm{m}$. (G, H, and I) A few GFPpositive cells (green, arrowhead) were simultaneously positive for Pax7 antibody (red, arrowhead). The merged image showed not only these cells (arrowhead), but also cells positive for GFP alone (green, arrows), and non-GFP expressing Pax7-positive cells (red, asterisk). Blue: nuclei. Bar: $10 \mu \mathrm{m}$. orifice. We showed that the autologous bone-marrowderived cells implanted into the wounded regions promoted the recovery of urinary sphincters composed of striated and smooth muscle cells.

At 7 and 14 days, both the myoglobin- and SMAexpressing areas of the cell-implanted regions were larger than those of the cell-free injected control ones. Some of the myoglobin- or SMA-positive cells were simultaneously positive for GFP antibody. Just before the implantation, the cultured cells were positive for GFP antibody; however, they were negative for myoglobin or SMA antibody. We focused only on the implanted cells that maintained expression of GFP after implantation. At 7 days, the majority of both GFP and myoglobin or SMA double-positive cells were mononuclear. While we cannot definitively exclude the possibility of cellular fusion, the findings suggest that the number of these double-positive cells formed by cellular fusion was small. Thus, the GFP-labeled implanted cells differentiated into myoglobin-positive striated muscle-like cells and SMA-positive smooth muscle-like cells within the injured regions.

Bone-marrow-derived cells can produce cytokines and growth factors that accelerate healing in damaged tissues. ${ }^{41,42}$ We do not yet know if the implanted cells secreted trophic factors that promoted differentiation of endogenous cells. Thus, there is the potential that a portion of the regenerated muscle layers were formed in response to trophic factors secreted from the implanted cells. Bone-marrowderived cells have the unique ability to differentiate into target cells and promote healing activities. However, these abilities are expressed only in suitable environments. Human urethral sphincters with intrinsic deficiency-related SUI have not been investigated to determine if the damaged regions provide such an environment that supports regeneration by bone-marrow-derived cells. To achieve clinically significant regeneration with these cells, it may be necessary to combine them with tissue engineering techniques that utilize scaffolds and/or growth factors. ${ }^{43}$ In any case, our study clearly showed that in rabbits the injection of bone-marrow-derived cells accelerated the recovery of urinary sphincters compared to cell-free injections.

At 7 days after implantation, cells double-positive for GFP and myoglobin and cells double-positive for GFP and SMA were present within the wound region as isolated cells that were not in physical contact with each other. In contrast, by 14 days the GFP and myoglobin double-positive cells were in contact with each other and with non-GFP expressing striated cells derived from uninjured surrounding tissues. Similarly, the GFP and SMA double-positive cells also contacted each other and non-GFP expressing smooth muscle 
FIG. 7. Reconstruction of layered muscle structures composed of striated and smooth musclelike cells differentiated from autologous bone-marrow-derived cells. (A-C) At 14 days after implantation, the both GFP-positive (A, green, arrowheads) and myoglobin-positive (B, red, arrowheads) cells were in contact with each other, and reconstructed the muscle layers (C, arrowheads). Blue: nuclei. Bar: $20 \mu \mathrm{m}$. (D-F) Similarly, the both GFP (D, green, arrows) and SMA (E, red, arrows) were also in contact with each other, and reconstructed the muscle layers (F, arrows). Blue: nuclei. Bar: $20 \mu \mathrm{m}$. (G-I) Smooth muscle-like cells differentiated from the implanted cells constructed blood vessel-like structures (arrows). Blue: nuclei. Bar: $20 \mu \mathrm{m}$. (J-L) Some GFP-labeled cells were simultaneously positive for Pax7 antibody (asterisks). Blue: nuclei. Bar: $10 \mu \mathrm{m}$.
GFP

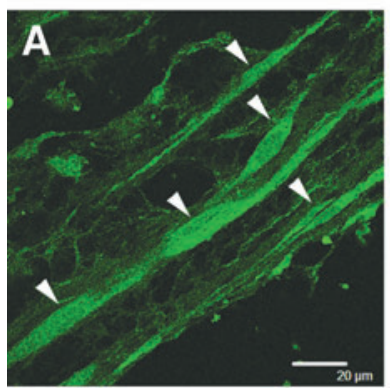

GFP
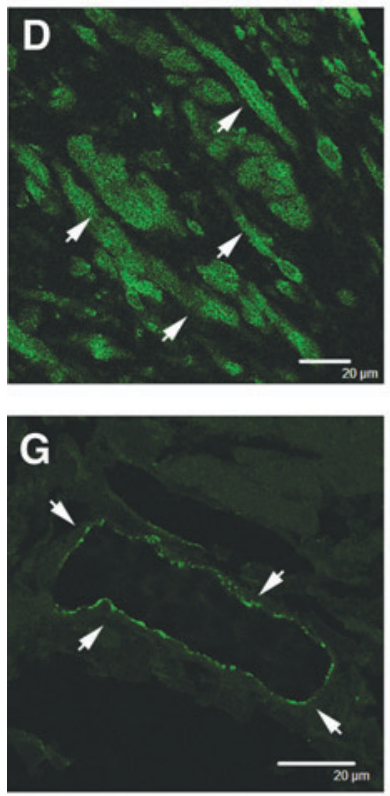

GFP

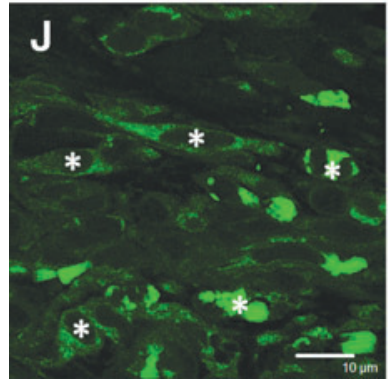

Myoglobin

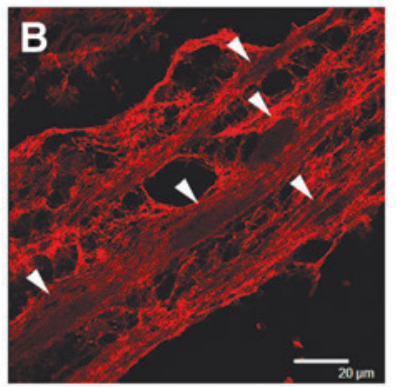

SMA
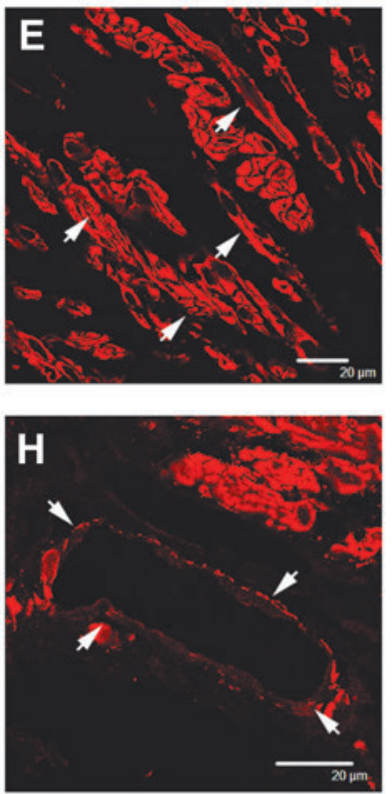

$\operatorname{Pax} 7$

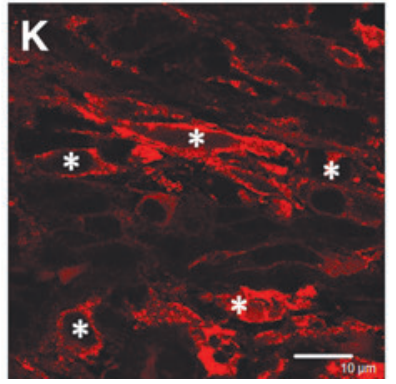

Merged image

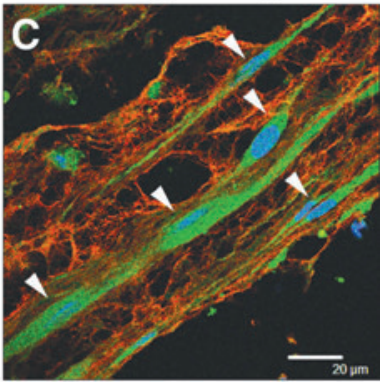

Merged image
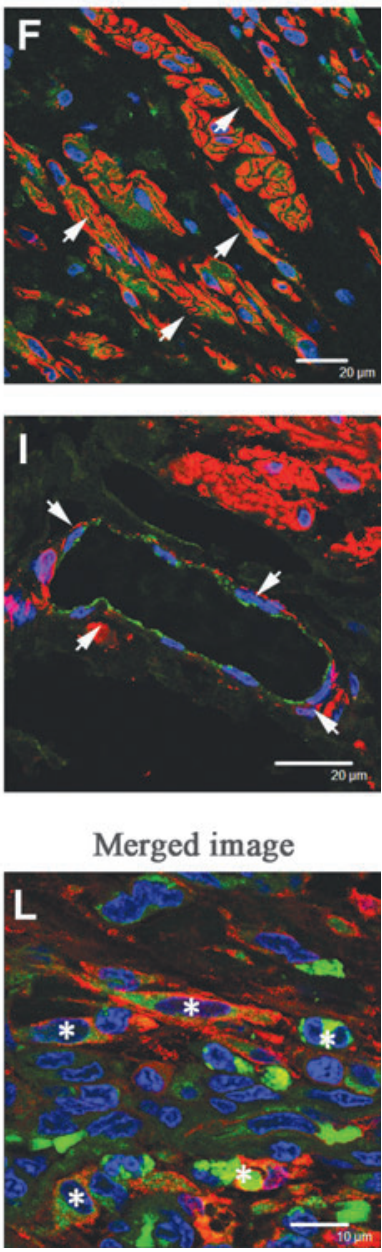

cells. The association of these cells formed higher order layered muscle structures within the urethral sphincters. In addition, the differentiated smooth muscle-like cells were also present in vessel-like structures. These results suggested that the striated muscle- and smooth muscle-like cells derived from implanted bone-marrow-derived cells might advance the reconstruction of muscle tissues and vascular components to support them.

At 7 days after cell implantation, a few of the GFP-labeled implanted cells were simultaneously positive for Pax7, suggesting that they had myoblast-like properties. However, by 14 days, the number of the cells expressing both GFP and Pax7 were distinctly higher compared to day 7. The myoblasts properly differentiate into striated or smooth muscle cells according to surrounding environment. We believe that the distinct presence of myoblast-like cells at 14 days suggests that recovery of the muscle tissues might have stopped further development of the GFP-Pax7 double-positive myoblasts into striated or smooth muscle cells. ${ }^{43}$ Understanding the controls for differentiation of the implanted cells is very important for the further development of regenerative medicine. While we do not understand the regulatory controls that govern the differentiation of the urethral striated and smooth muscle cells, it is clear that the presence of the myoblasts in the regenerated region may have important long-term significance. In the event that the newly differentiated striated and/or smooth muscle-like tissues and structures spontaneously regress or are lost for other reasons, the 

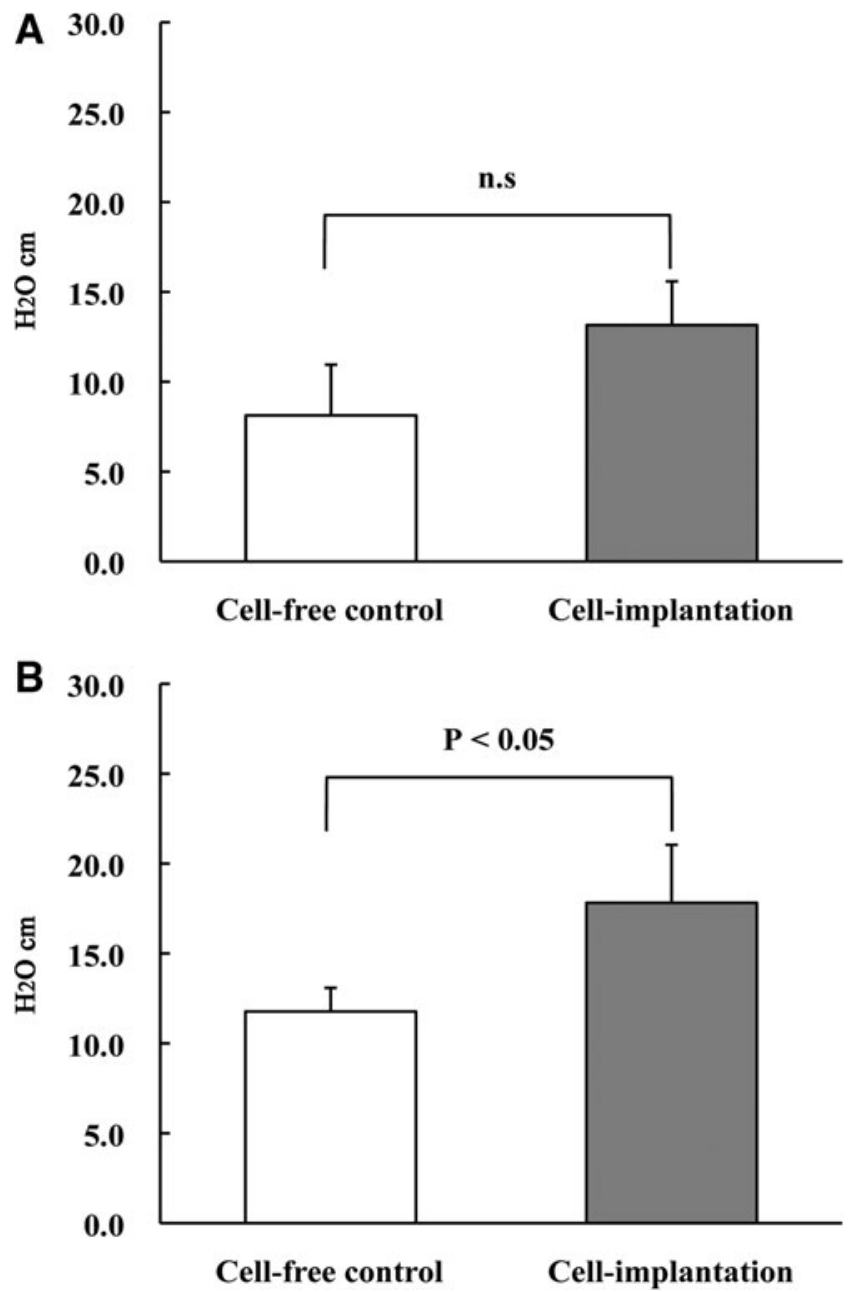

FIG. 8. Leak point pressures. (A) At 7 days, the leak point pressure of cell-implantation group (right bar) was slightly higher than the control group (left bar), but the difference was not significant ( $n=4$, in each group). n.s, no significance. (B) At 14 days, the leak point pressure of the cell-implantation group (right bar) was significantly higher than that of the control group (left bar, $n=4$ in each group).

presence of the myoblast-like cells could ensure the replacement of the lost cells. Thus, the effects of treatments might be maintained for long time.

Like other models of intrinsic sphincter deficiency-related SUI, ${ }^{44-47}$ our experimental rabbits lost urethral sphincter tissues composed of typical striated and smooth muscle cells, and exhibited lower leak point pressures compared to sham-injured rabbits. The urinary sphincters of patients with intrinsic sphincter deficiency-related SUI are considered to be irreversibly damaged. However, this appears not to be the case in our model system. The cell-free injected control rabbits showed a weak but natural recovery of striated and smooth muscle cells accompanied by a slight increase in leak point pressure. We intentionally avoided more severe and serious sphincter damage that would have produced irreversible incontinence because of the potential for urethral stricture or perforation, followed by death. Thus, our model is considered to be an acute incontinence of relatively short duration.
While our animal model of intrinsic sphincter deficiency SUI may have some limitations, 7 days after cell implantation, the leak point pressure increased slightly compared to the cell-free injected controls, and by 14 days the improvement was statistically significant. The close correlation of these changes with the accompanying structural changes in the sphincter suggested that the improvement was related to the recovery of muscle layers. However, we do not yet know the leak point pressures of healthy rabbits, and whether or not the rabbits had voluntary control of the sphincters. Clinically, while $<60-65 \mathrm{~cm} \mathrm{H}_{2} \mathrm{O}$ of (abdominal) leak point pressure is one of the indexes of SUI, it is not sufficient to diagnose SUI. Nevertheless, it is clear that increased or a high leak point pressure is helpful to inhibit urine leakage that can occur during physical activity. Therefore, cell therapy using bone-marrow-derived cells has a great potential to improve urinary incontinence and quality of life.

In conclusion, autologous bone-marrow-derived cells implanted into injured rabbit urethral sphincters differentiated into striated or smooth muscle-like cells. The differentiated cells became organized into layered muscle structures. Recovery of the urethral sphincters was accompanied by improved urethral closure pressure for prohibiting the inadvertent release of urine. Therefore, the implantation of autologous bone-marrow-derived cells has great potential to be an effective treatment for the intrinsic sphincter deficiency-related SUI.

\section{Disclosure Statement}

No competing financial interests exist.

\section{References}

1. Nygaard, I.E., and Heit, M. Stress urinary incontinence. Obstet Gynecol 104, 607, 2004.

2. Hampel, C., Wienhold, D., Benken, N., Eggersmann, C., and Thuroff, J.W. Prevalence and natural history of female incontinence. Eur Urol 32 Suppl 2, 3, 1997.

3. Smaldone, M.C., Chen, M.L., and Chancellor, M.B. Stem cell therapy for urethral sphincter regeneration. Minerva Urol Nefrol 61, 27, 2009.

4. del Canto, M., Bielsa, O., Lorente, J.A., Castillo, M., Carreras, R., and Arango, $\mathrm{O}$. The use of tension-free vaginal tape associated with pelvic floor reconstructive surgery. Actas Urol Esp 33, 1097, 2009.

5. Ignjatovic, I., Stojkovic, I., Basic, D., Medojevic, N., and Potic, M. Optimal primary minimally invasive treatment for patients with stress urinary incontinence and symptomatic pelvic organ prolapse: tension free slings with colporrhaphy, or prolift with the tension free midurethral sling? Eur J Obstet Gynecol Reprod Biol 150, 97, 2010.

6. Su, T.H., Huang, W.C., Lee, M.Y., Lin, T.Y., Chang, H.C., and Chen, C.P. Tension-free vaginal tape-obturator procedure for treatment of severe urodynamic stress incontinence: subjective and objective outcomes during 2 years of followup. J Obstet Gynaecol Res 35, 1077, 2009.

7. Bakas, P., Liapis, A., Giner, M., and Creatsas, G. Quality of life in relation to TVT procedure for the treatment of stress urinary incontinence. Acta Obstet Gynecol Scand 85, 748, 2006.

8. Tomoe, H., Kondo, A., Takei, M., Nakata, M., and Toma, H. Quality of life assessments in women operated on by tension-free vaginal tape (TVT). Int Urogynecol J Pelvic Floor Dysfunct 16, 114, 2005. 
9. Vassallo, B.J., Kleeman, S.D., Segal, J.L., Walsh, P., and Karram, M.M. Tension-free vaginal tape: a quality-of-life assessment. Obstet Gynecol 100, 518, 2002.

10. Fritel, X., Fauconnier, A., and Pigne, A. Circumstances of leakage related to low urethral closure pressure. J Urol 180, 223, 2008

11. Bauer, R.M., Bastian, P.J., Gozzi, C., and Stief, C.G. Postprostatectomy incontinence: all about diagnosis and management. Eur Urol 55, 322, 2009.

12. Romano, S.V., Metrebian, S.E., Vaz, F., Muller, V., D'Ancona, C.A., Costa, D.E.S.E.A., and Nakamura, F. An adjustable male sling for treating urinary incontinence after prostatectomy: a phase III multicentre trial. BJU Int 97, 533, 2006.

13. Huang, W.C., and Yang, J.M. Bladder neck funneling on ultrasound cystourethrography in primary stress urinary incontinence: a sign associated with urethral hypermobility and intrinsic sphincter deficiency. Urology 61, 936, 2003.

14. Betson, L.H., Siddiqui, G., and Bhatia, N.N. Intrinsic urethral sphincteric deficiency: critical analysis of various diagnostic modalities. Curr Opin Obstet Gynecol 15, 411, 2003.

15. Ghoniem, G.M., Elgamasy, A.N., Elsergany, R., and Kapoor, D.S. Grades of intrinsic sphincteric deficiency (ISD) associated with female stress urinary incontinence. Int Urogynecol J Pelvic Floor Dysfunct 13, 99, 2002.

16. Kryger, J.V., Gonzalez, R., and Barthold, J.S. Surgical management of urinary incontinence in children with neurogenic sphincteric incompetence. J Urol 163, 256, 2000.

17. Haab, F., Zimmern, P.E., and Leach, G.E. Female stress urinary incontinence due to intrinsic sphincteric deficiency: recognition and management. J Urol 156, 3, 1996.

18. Rovner, E.S., and Goudelocke, C.M. Which injectable to use in the treatment of intrinsic sphincter deficiency? Curr Opin Urol 20, 296, 2010.

19. Kotb, A.F., Campeau, L., and Corcos, J. Urethral bulking agents: techniques and outcomes. Curr Urol Rep 10, 396, 2009.

20. Herschorn, S. Current role of injectable agents for female stress urinary incontinence. Can J Urol 13 Suppl 1, 5, 2006.

21. Lightner, D.J., Itano, N.B., Sweat, S.D., Chrouser, K.L., and Fick, F. Injectable agents: present and future. Curr Urol Rep 3, 408, 2002.

22. Comiter, C.V. Surgery insight: surgical management of postprostatectomy incontinence-the artificial urinary sphincter and male sling. Nat Clin Pract Urol 4, 615, 2007.

23. O'Connor, R.C., Nanigian, D.K., Patel, B.N., Guralnick, M.L., Ellision, L.M., and Stone, A.R. Artificial urinary sphincter placement in elderly men. Urology 69, 126, 2007.

24. Lightner, D.J. Review of the available urethral bulking agents. Curr Opin Urol 12, 333, 2002.

25. Gorton, E., Stanton, S., Monga, A., Wiskind, A.K., Lentz, G.M., and Bland, D.R. Periurethral collagen injection: a longterm follow-up study. BJU Int 84, 966, 1999.

26. Magera, J.S., Jr., and Elliott, D.S. Tandem transcorporal artificial urinary sphincter cuff salvage technique: surgical description and results. J Urol 177, 1015, 2007.

27. Petrou, S.P., Pak, R.W., and Lightner, D.J. Simple aspiration technique to address voiding dysfunction associated with transurethral injection of dextranomer/hyaluronic acid copolymer. Urology 68, 186, 2006.

28. Sweat, S.D., and Lightner, D.J. Complications of sterile abscess formation and pulmonary embolism following periurethral bulking agents. J Urol 161, 93, 1999.

29. Benshushan, A., Brzezinski, A., Shoshani, O., and Rojansky, N. Periurethral injection for the treatment of urinary incontinence. Obstet Gynecol Surv 53, 383, 1998.
30. Furuta, A., Jankowski, R.J., Pruchnic, R., Yoshimura, N., and Chancellor, M.B. The promise of stem cell therapy to restore urethral sphincter function. Curr Urol Rep 8, 373, 2007.

31. Drost, A.C., Weng, S., Feil, G., Schafer, J., Baumann, S., Kanz, L., Sievert, K.D., Stenzl, A., and Mohle, R. In vitro myogenic differentiation of human bone marrow-derived mesenchymal stem cells as a potential treatment for urethral sphincter muscle repair. Ann N Y Acad Sci 1176, 135, 2009.

32. Peister, A., Mellad, J.A., Larson, B.L., Hall, B.M., Gibson, L.F., and Prockop, D.J. Adult stem cells from bone marrow (MSCs) isolated from different strains of inbred mice vary in surface epitopes, rates of proliferation, and differentiation potential. Blood 103, 1662, 2004.

33. Jaiswal, R.K., Jaiswal, N., Bruder, S.P., Mbalaviele, G., Marshak, D.R., and Pittenger, M.F. Adult human mesenchymal stem cell differentiation to the osteogenic or adipogenic lineage is regulated by mitogen-activated protein kinase. J Biol Chem 275, 9645, 2000.

34. Pittenger, M.F., Mackay, A.M., Beck, S.C., Jaiswal, R.K., Douglas, R., Mosca, J.D., Moorman, M.A., Simonetti, D.W., Craig, S., and Marshak, D.R. Multilineage potential of adult human mesenchymal stem cells. Science 284, 143, 1999.

35. Kushida, T., Inaba, M., Ikebukuro, K., Ngahama, T., Oyaizu, H., Lee, S., Ito, T., Ichioka, N., Hisha, H., Sugiura, K., Miyashima, S., Ageyama, N., Ono, F., Iida, H., Ogawa, R., and Ikehara, S. A new method for bone marrow cell harvesting. Stem Cells 18, 453, 2000.

36. Imamura, T., Kinebuchi, Y., Ishizuka, O., Seki, S., Igawa, Y., and Nishizawa, $\mathrm{O}$. Implanted mouse bone marrow-derived cells reconstruct layered smooth muscle structures in injured urinary bladders. Cell Transplant 17, 267, 2008.

37. Carr, L.K., Steele, D., Steele, S., Wagner, D., Pruchnic, R., Jankowski, R., Erickson, J., Huard, J., and Chancellor, M.B. 1Year follow-up of autologous muscle-derived stem cell injection pilot study to treat stress urinary incontinence. Int Urogynecol J Pelvic Floor Dysfunct 19, 881, 2008.

38. Mitterberger, M., Pinggera, G.M., Marksteiner, R., Margreiter, E., Fussenegger, M., Frauscher, F., Ulmer, H., Hering, S., Bartsch, G., and Strasser, H. Adult stem cell therapy of female stress urinary incontinence. Eur Urol 53, 169, 2008.

39. Mitterberger, M., Marksteiner, R., Margreiter, E., Pinggera, G.M., Colleselli, D., Frauscher, F., Ulmer, H., Fussenegger, M., Bartsch, G., and Strasser, H. Autologous myoblasts and fibroblasts for female stress incontinence: a 1-year follow-up in 123 patients. BJU Int 100, 1081, 2007.

40. Lin, G., Wang, G., Banie L., Ning, H., Shindel, A.W., Fandel, T.M., Lue, T.F., and Lin, C.S. Treatment of stress urinary incontinence with adipose tissue-derived stem cells. Cytotherapy 12, 88, 2010.

41. Huang, N.F., Lam, A., Fang, Q., Sievers, R.E., Li, S., and Lee, R.J. Bone marrow-derived mesenchymal stem cells in fibrin augment angiogenesis in the chronically infarcted myocardium. Regen Med 4, 527, 2009.

42. Matsushima, A., Kotobuki, N., Tadokoro, M., Kawate, K., Yajima, H., Takakura, Y., and Ohgushi, H. In vivo osteogenic capability of human mesenchymal cells cultured on hydroxyapatite and on beta-tricalcium phosphate. Artif Organs 33, 474, 2009.

43. Imamura, T., Yamamoto, T., Ishizuka, O., Gotoh, M., and Nishizawa, O. The microenvironment of freeze-injured mouse urinary bladders enables successful tissue engineering. Tissue Eng Part A 15, 3367, 2009.

44. Kinebuchi, Y., Aizawa, N., Imamura, T., Ishizuka, O., Igawa, Y., and Nishizawa, O. Autologous bone-marrow-derived 
mesenchymal stem cell transplantation into injured rat urethral sphincter. Int J Urol 17, 359, 2010.

45. Peng, C.W., Chen, J.J., Chang, H.Y., de Groat, W.C., and Cheng, C.L. External urethral sphincter activity in a rat model of pudendal nerve injury. Neurourol Urodyn 25, 388, 2006.

46. Chermansky, C.J., Cannon, T.W., Torimoto, K., Fraser, M.O., Yoshimura, N., de Groat, W.C., and Chancellor, M.B. A model of intrinsic sphincteric deficiency in the rat: electrocauterization. Neurourol Urodyn 23, 166, 2004.

47. Yiou, R., Yoo, J.J., and Atala, A. Restoration of functional motor units in a rat model of sphincter injury by muscle precursor cell autografts. Transplantation 76, 1053, 2003.
Address correspondence to: Tetsuya Imamura, Ph.D. Department of Urology Shinshu University School of Medicine 3-1-1 Asahi Matsumoto 390-8621

Japan

E-mail: imatetu@shinshu-u.ac.jp

Received: August 13, 2010 Accepted: November 22, 2010 Online Publication Date: January 12, 2011 
